\title{
Investigating relationship between religious commitment and moral sensitivity in nurses working in ICU
}

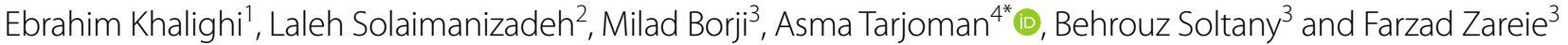

\begin{abstract}
Objectives: This study aimed at determining the relationship between religious commitment and moral sensitivity among nurses working in the ICU sections in the west of Iran. The present study was a cross-sectional descriptiveanalytic study carried out on nurses working in ICU wards of two western cities in Iran. The instrument used includes a demographic questionnaire, religious commitment questionnaire and moral sensitivity questionnaire in nurses. First, the researchers referred to the ICU wards of the hospitals in the cities after receiving permission from the relevant authorities by referring to three shifts in the morning, evening and night shifts and holidays. The researchers, while explaining the research goals for the nurses participating in the study, obtained their informed consent to participate in this study.

Results: According to the findings, mean (SD) of the overall score of religious commitment was equal to 36.38 (4.58) and mean (SD) of MS score of nurses was 59.21 (12.65). Also, 91 nurses (82.7\%) had average MS, 7 (6.4\%) had low MS and 12 (10.9\%) had high MS.
\end{abstract}

Keywords: Religious commitment, Moral sensitivity, Nurse

\section{Introduction}

Moral sensitivity causes the nurse to better manage and treat patients in relation to the therapeutic and non-therapeutic measures [1]. Moral sensitivity makes the nurse susceptible to ethical issues in the professional environment and, by increasing the amount of power of diagnosing ethics issues, obtains the skill required to acquire problem-solving skills in ethical dilemmas [2, 3].

Religious commitment means thinking, feeling and behaving in accordance with the beliefs and teachings of a religion $[4,5]$. In fact, it can be said that religious commitment shows how religion is in the personal and social life of man. Religious commitment also reflects respect for values and adherence to beliefs in everyday life and

\footnotetext{
*Correspondence: Asmatarjoman@yahoo.com

${ }^{4}$ Student Research Committee, Kermanshah University of Medical

Sciences, Kermanshah, Iran

Full list of author information is available at the end of the article
}

religious practices $[5,6]$. Religious commitment has two dimensions of intra-individual and extra-individual. The intra-individual religious commitment means the value of a person's religious beliefs and a degree of commitment and loyalty to the religion. The extra-individual religious commitment is said to be relative to the willingness of a person to engage in religious activities [7, 8]. Regarding the role and importance of spirituality in health [9] as well as the role of observance of professional ethics by nurses in improving the health status of patients.

\section{Main text \\ Methods}

This study aimed at determining the relationship between religious commitment and moral sensitivity among nurses working in the ICU sections of Ilam and Kermanshah cities in the west of Iran. The present study was a cross-sectional descriptive-analytic study carried 
out on 110 nurses working in ICU wards of two western cities (Ilam and Kermanshah) in Iran. The entry criteria included having at least a bachelor's degree in nursing, having a work experience of more than 1 year in the ICU and informed consent for participation in the study.

First, the researchers referred to the ICU wards of the hospitals in the cities of Ilam and Kermanshah after receiving permission from the relevant authorities by referring to three shifts in the morning, evening and night shifts and holidays. The researchers, while explaining the research goals for the nurses participating in the study, obtained their informed consent to participate in this study. Then, the nurses were assured that their participation did not have any harm or loss to them, and the information obtained from these nurses would be reported anonymously. The questionnaire was then provided to the nurses and they were asked to complete the questionnaire when they were willing. Given that the nurses' fatigue may have prevented them from completing with the questionnaires accurately, they were asked to complete the questionnaire at the time of rest and to have sufficient time. The questionnaires were collected on the next day. The hospitals that were visited in Ilam included ICU's of Imam Khomeini Hospital, Martyr Mostafa Khomeini Hospital and Ayatollah Taleghani Hospital. Also, in the city of Kermanshah, ICU sections of Ayatollah Taleghani, Imam Khomeini, Imam Reza and Imam Ali hospitals were investigated.

The instrument used includes a demographic questionnaire, religious commitment questionnaire and moral sensitivity questionnaire in nurses. Religious Commitment Questionnaire had 10 items in two dimensions: intra-individual religious commitment (6 questions) and extra-individual religious commitment (4 questions) in the form of 5-point Likert scale, which describes the level of religious commitment of a person [3]. The questionnaire of moral sensitivity in nursing had 25 items, which includes the amount of respect for patient independence, the level of awareness of how to communicate with the patient, the level of professional knowledge, the experience of problems and ethical conflicts, the use of ethical concepts in moral decision-making and honesty and benevolence. A five-point Likert scale was used from zero (no idea) to four (totally agree) and the scores ranged from zero to 50 (low moral sensitivity), 50 to 75 (a moderate moral sensitivity), 76 to 100 (a high moral sensitivity $[10,11]$. Data using software spss 16 were analyzed using descriptive statistics (mean and standard deviation) and analytical tests (independent $\mathrm{t}$-test, ANOVA and regression).

\section{Findings}

According to the findings, $\mathrm{MS}$ and $\mathrm{RC}$ rates in female nurses, having MA degree and higher were higher than male nurses with BA degree which was statistically significant. Moreover, with the increase in age and work experience, the nurse MS and $\mathrm{RC}$ also increased, which were statistically significant (Tables 1, 2, 3).

\section{Discussion}

In the study of Baloochi Beydokhti et al. on the nurses' group of Gonabad city of Iran, it was shown that the amount of internal religious orientation was higher than the external religious orientation and there was a significant weak relationship between the amount of internal religious orientation and the rate of MS [12] which showed the relationship between religion and MS in nurses. In the study of Farahaninia et al. on the nursing students, the implementation of six sessions of the ethical intervention program can lead to an increase

Table 1 Mean (SD) of religious commitment and moral sensitivity in nurses working in the ICU participating in the research

\begin{tabular}{lllll}
\hline & Status & N (\%) & RC & MS \\
\hline Sex & Man & $47(42.7)$ & $34.97(5.64)$ & $53.25(13.30)$ \\
& Female & $63(57.3)$ & $37.42(3.28)$ & $63.66(10.15)$ \\
Level of education & P, F & & $F=8.17, P=0.005$ & $F=21.67, P=0.000$ \\
& Below Masters & $61(55.5)$ & $35.57(5.39)$ & $56.42(13.26)$ \\
Marital status & Master of Science and above & $49(44.5)$ & $37.38(2.75)$ & $62.69(11.02)$ \\
& P, F & & $F=4.37, P=0.03$ & $F=7.03, P=0.009$ \\
& Single & $64(58.2)$ & $36.04(4.71)$ & $57.57(14.20)$ \\
History ethics workshop & Married & $46(41.8)$ & $36.84(4.41)$ & $61.50(9.82)$ \\
& P, F & & $F=0.84, P=0.36$ & $F=2.60, P=0.10$ \\
& Yes & $62(56.4)$ & $36.53(3.95)$ & $59.90(11.44)$ \\
& No & $48(43.6)$ & $36.18(5.33)$ & $58.33(14.14)$ \\
& & & $F=0.15, P=0.69$ & $F=0.41, P=0.52$ \\
\hline
\end{tabular}


Table 2 Mean (SD) religious commitment score and ethical sensitivity with their dimensions in the ICU participating in the research

\begin{tabular}{lrr}
\hline & SD & Mean \\
\hline Religious commitment & & \\
Internal religious commitment & 23.10 & 3.10 \\
External religious commitment & 13.27 & 2.65 \\
Total religious commitment score & 36.38 & 4.58 \\
Then respect for patient independence & 7.33 & 3.08 \\
Then awareness of how to communicate with the & 13.04 & 3.33 \\
$\quad$ patient & & \\
Moral sensitivity & & \\
Professional knowledge later & 5.26 & 1.66 \\
Then experience moral problems & 5.76 & 2.36 \\
Then use ethical concepts in moral decision making & 10.57 & 3.29 \\
Then sincerity and goodwill & 17.23 & 4.65 \\
Total moral sensitivity score & 59.21 & 12.65 \\
\hline
\end{tabular}

Table 3 Relationship between RC wite MS

\begin{tabular}{llrcrc}
\hline Model & Sum of squares & Df & Mean square & F & Sig. \\
\hline MS & & & & & \\
Regression & 8286.550 & 1 & 8286.550 & 97.572 & 0.000 \\
Residual & 9172.214 & 108 & 84.928 & & \\
Total & 174.58 .764 & 109 & & & \\
\hline
\end{tabular}

in the MS score of nursing students [13], which confirms the role of religious factors in nurses' MS status.

In this study, the MS mean score for most nurses was average and equal to $(M=59.21)(S D=12.65)$. Various studies have been performed on the rate of MS in nurses working in the intensive care units of Iran and their results were compared with the results of this study. In the study of Mohammadi et al. on the nurses working in the specialized care units of South Khorasan province in Iran, the results showed that the MS score of nurses was average and upward with a score of 3.05 (0.68) out of a total of 4. It was also shown that by increasing the MS score, the attitude score toward patient's rights was also increased [14]. Different studies have been conducted on nurses working in non-specialized care units of Iran.

\section{Conclusion}

According to the results, it is necessary to take necessary religious interventions to improve the rate of $\mathrm{RC}$ in nurses so as to provide the necessary field in order to improve the status of MS.

\section{Limitation}

Small sample size.

\section{Abbreviation}

ICU: intensive care unit.

\section{Acknowledgements}

Student Research Committee, Kermanshah University of Medical Sciences, Iran.

Authors' contributions

EK, BS and MB contributed in designing the study, FZ, BS and LS collected the data, and analyzed by AT, LS and FZ, the final report and article were written by MB, EK, and AT. All authors read and approved by all the authors.

Funding

Grant number: 3008282

\section{Availability of data and materials}

Data are available upon request.

\section{Ethics approval and consent to participate}

The study was approved by research ethics committee of Kermanshah University of Medical Sciences (IR.KUMS.REC.1398.390). The written informed consent was obtained from all the participants.

\section{Consent to publish}

Not applicable.

\section{Competing interests}

The authors declare that they have no competing interests.

\section{Author details}

${ }^{1}$ Department of Anesthesiology, Medicine Faculty, Ilam University of Medical Science, Ilam, Iran. ${ }^{2}$ Department of Nursing, Faculty of Nursing and Midwifery, Bam University of Medical Science, Bam, Iran. ${ }^{3}$ Department of Nursing, Faculty of Nursing and Midwifery, Kermanshah University of Medical Science, Kermanshah, Iran. ${ }^{4}$ Student Research Committee, Kermanshah University of Medical Sciences, Kermanshah, Iran.

Received: 19 October 2019 Accepted: 20 January 2020

Published online: 28 January 2020

\section{References}

1. Kim Y-S, Park J-W, You M-A, Seo Y-S, Han S-S. Sensitivity to ethical issues confronted by Korean hospital staff nurses. Nurs Ethics. 2005;12(6):595-605.

2. Borhani F, Abbaszadeh A, Mohsenpour M. Nursing students' understanding of factors influencing ethical sensitivity: a qualitative study. Iran J Nurs Midwifery Res. 2013;18(4):310.

3. Baykara ZG, Demir SG, Yaman SJ. The effect of ethics training on students recognizing ethical violations and developing moral sensitivity. Nurs Ethics. 2015;22(6):661-75.

4. Hill PC, Pargament Kl, Hood RW, McCullough J, Michael E, Swyers JP, Larson DB, et al. Conceptualizing religion and spirituality: points of commonality, points of departure. J Theory Soc Behav. 2000;30(1):51-77.

5. Parsafar S, Namdari K, Hashemi SE, Mehrabi HA. The relationship between religious commitment, unforgiveness and forgiveness styles with the mental health. 2015

6. McCullough ME, Larson DB. Religion and depression: a review of the literature. Twin Res Hum Genet. 1999:2(2):126-36.

7. Mattingly BA, Wilson K, Clark EM, Bequette AW, Weidler DJ. Foggy faithfulness: relationship quality, religiosity, and the perceptions of dating infidelity scale in an adult sample. J Fam Issues. 2010;31(11):1465-80. 
8. Radmehr H, Shams J. Examining the association between religious commitment and marital stability among divorce-seeking and normal couples in Tehran. J Res Relig Health. 2019;4(5):77-86.

9. Shahrbabaki PM, Nouhi E, Kazemi M, Ahmadi F. Spirituality: a panacea for patients coping with heart failure. Int J Community Based Nurs Midwifery. 2017;5(1):38.

10. Hassanpoor M, Hosseini M, Fallahi Khoshknab M, Abbaszadeh A. Evaluation of the impact of teaching nursing ethics on nurses' decision making in Kerman social welfare hospitals in 1389. Iran J Med Ethics Hist Med. 2011;4(5):58-64.

11. Izadi A, Imani H, Noughabi F, Hajizadeh N, Naghizadeh F. Moral sensitivity of critical care nurses in clinical decision making and its correlation with their caring behavior in teaching hospitals of Bandar Abbas in 2012. Iran J Med Ethics Hist Med. 2013;6(2):43-56.

12. Baloochi Beydokhti T, Tolide-ie H, Fathi A, Hoseini M, Gohari Bahari S. Relationship between religious orientation and moral sensitivity in the decision making process among nurses. Iran J Med Ethics Hist Med. 2014;7(3):48-57.

13. Farahaninia M, Ekramifar F, Mardani Hamooleh M, Haghani $H$. The effect of spiritual training on the moral sensitivity of nursing students. JCCNC. 2018;4(4):213-22.

14. Mohammady S, Borhani F, Roshanzadeh M. Moral sensitivity and nurse's attitude toward patients' rights. Iran J Med Ethics Hist Med. 2017;9(5):52-62.

\section{Publisher's Note}

Springer Nature remains neutral with regard to jurisdictional claims in published maps and institutional affiliations.
Ready to submit your research? Choose BMC and benefit from:

- fast, convenient online submission

- thorough peer review by experienced researchers in your field

- rapid publication on acceptance

- support for research data, including large and complex data types

- gold Open Access which fosters wider collaboration and increased citations

- maximum visibility for your research: over $100 \mathrm{M}$ website views per year

At BMC, research is always in progress.

Learn more biomedcentral.com/submissions 